\title{
SEROPREVALENCE OF CHAGAS DISEASE IN SCHOOLCHILDREN FROM TWO MUNICIPALITIES OF JEQUITINHONHA VALLEY, MINAS GERAIS, BRAZIL; SIX YEARS FOLLOWING THE ONSET OF EPIDEMIOLOGICAL SURVEILLANCE
}

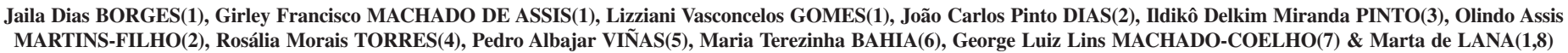

\begin{abstract}
SUMMARY
Six years after the beginning of the epidemiological surveillance of Chagas disease in Berilo and José Gonçalves de Minas, Jequitinhonha Valley, MG, Brazil, a serological inquiry was performed to observe whether the transmission of this endemy was occurring in this area. A randomized sample of 1,412 children seven to 14 years old, was screened. Six asymptomatic children were found to be positive, leading to $0.4 \%$ of prevalence. Hemoculture confirmed infection in five out of the six positive cases. Additional epidemiological investigation revealed important antecedents, such as disease reports in relatives and predisposing ecological and housing conditions. Our results demonstrated similar seroprevalence $(0.4 \%)$ in schoolchildren, ranging from seven to 14 years old, and that were observed six years ago $(0.2 \%)$ for children $0-9$ year-old. Thus, considering the constant presence of Panstrogylus megistus in the peridomicile these findings emphasize the need of continuous improved epidemiological surveillance of Chagas disease in this region.
\end{abstract}

KEYWORDS: Chagas disease prevalence; Serology; Children.

\section{INTRODUCTION}

The current estimation of the World Health Organization indicates a prevalence of Trypanosoma cruzi infection around 13 million people in 15 countries, with an annual incidence of 200,000 cases (http:// who.int/tdr/dw/chagas2003.htm). In Brazil, the municipality of Berilo, Jequitinhonha Valley, North of Minas Gerais state, was considered one of the most endemic areas for Chagas disease infection before the establishment of a systematic vector control ${ }^{12}$, with a global prevalence of $35.5 \%$ and $68.4 \%$ when considering the population more than 39 years old. Since 1960, vectorial control activities have been carried out in Berilo. However, the control program was continuously executed only between 1970 and 1980. After these effective vector control practices, a serological survey performed in 1997, including 2,261 volunteers, indicated a Chagas disease infection prevalence of $18.0 \%$ with rare cases of positivity observed in children under 10 years of age $(0.17 \%)$, suggesting interruption of the vectorial transmission of the disease and success in vector control actions ${ }^{23}$.

The frequent finding of Panstrongylus megistus in this region, a sylvatic and peridomiciliary secondary vector, emphasizes the necessity of continuous epidemiological vector surveillance and serological inquiry for Chagas disease as proposed by National Foundation of Health (FUNASA). In 1982, an entomological study reported that 75\% of triatomine species captured were Panstrongylus megistus with $58.36 \%$ of them found at domiciliary environment including $13.1 \%$ of positivity to T. cruzi $^{6}$. Again, after 1980's the use of insecticide had a great impact in the number of captured insects and the occurrence of intradomiciliary vectors, as well as the positive impact reducing the global index of positive serology, found to be $12.7 \%$ lower in comparison to previous reports ${ }^{1}$.

Despite these clear benefits, vector control programs were interrupted from 1990 to 1991 and re-started, again, in 1992. However, focusing the importance of the control program for Chagas disease, in 1997, the FUNASA installed the epidemiological vector surveillance in Berilo and its district, José Gonçalves de Minas, considered thereafter a independent politically municipality. For this purpose, nineteen Triatomine Information Posts were installed, two in each urban area and 17 in the rural zone with the surveillance supervision of Health Decentralized Actions Directory from Diamantina, Minas Gerais State ${ }^{22}$. Recently, decentralization of the Brazilian Health System had a direct impact on the FUNASA attributions, with consequent discontinuity of its actions on the control of endemic Brazilian diseases, including Chagas disease.

(1)Núcleo de Pesquisas em Ciências Biológicas (NUPEB), Instituto de Ciências Exatas e Biológicas (ICEB), UFOP, Ouro Preto, MG, Brasil.

(2)Centro de Pesquisas René Rachou (CPqRR-FIOCRUZ/BH), Belo Horizonte, MG, Brasil

(3)Fundação Ezequiel Dias, Belo Horizonte, MG, Brasil.

(4)Departamento de Clínica Médica, Faculdade de Medicina, UFMG, Belo Horizonte, MG, Brasil.

(5)Departamento de Medicina Tropical, IOC-FIOCRUZ, Rio de Janeiro, RJ, Brasil.

(6)Departamento de Ciências Biológicas, ICEB, UFOP, Ouro Preto, MG, Brasil.

(7)Departamento de Farmácia, Escola de Farmácia, UFOP, Ouro Preto, MG, Brasil.

(8)Departamento de Análises Clínicas, Escola de Farmácia, Universidade Federal de Ouro Preto, MG, Brasil.

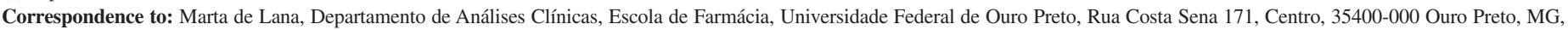
Brasil. 


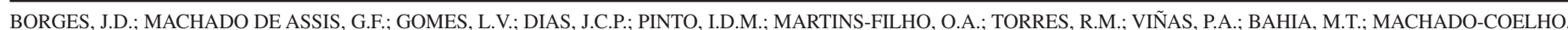
G.L.L. \& LANA, M. - Seroprevalence of Chagas disease in schoolchildren from two municipalities of Jequitinhonha Valley, Minas Gerais, Brazil; six years following the onset of epidemiological surveillance. Rev. Inst. Med. trop. S. Paulo, 48(2):81-86, 2006.

Taken together these remarks with the associated constant presence of $P$. megistus at peridomiciliary environment of these two municipalities, the main goal of the present investigation was to verify whether the transmission of Chagas disease still occurs in Berilo and José Gonçalves de Minas, Jequitinhonha Valley, Minas Gerais State, Brazil, and detailed clinical-laboratorial investigation of seropositive cases.

\section{SUBJECTS, MATERIAL AND METHODS}

Study area: Berilo and José Gonçalves de Minas are located at Jequitinhonha Valley, Northwest of Minas Gerais State, Brazil. This area has $968 \mathrm{~km}^{2}$ of extension and it is referred as one of the most important endemic areas for Chagas disease in Brazil. These two municipalities have 17,675 habitants, 12,979 from Berilo and 4,696 from José Gonçalves de Minas. According to the 2000 IBGE census, $78.43 \%$ of these individuals live in rural areas having an economy based on agriculture and cattle ranching activities.

Study population: To verify whether Chagas disease infection occurred in the last six years and a half, after the implantation of the epidemiological surveillance in the region, a cross sectional study was performed in seven to 14 year-old schoolchildren. This group was selected considering logistic facilities, $100 \%$ children school attendance and the possibility of comparing the present seroprevalence of this group of age with the former seroprevalence $(0.2 \%)$ found by MONTOYA et al. ${ }^{23}$ in the group aged zero to nine years old, in the same study area.

The study was performed between June and August, 2003, in schoolchildren living on urban and rural zones of both counties. The sample size was calculated based on: a) universe of 3,375 schoolchildren 7-14 year-old (2,200 from Berilo and 1,155 from José Gonçalves de Minas); b) expected frequency for Chagas disease $1.5 \%{ }^{1}$; c) precision of $1 \%$; d) confidence interval of $95 \%$ and e) lost of $10 \%$. Using these premises a sample estimated in 1,492 individuals was selected by single random process stratified by density of individuals in each school unit.

A total of 1,412 individuals (846 from Berilo and 566 from José Gonçalves de Minas) were involved in this investigation, including 666 males (451 from Berilo and 294 from José Gonçalves de Minas) and 746 females (395 from Berilo and 272 from José Gonçalves de Minas). Due to the rural access difficulties and feasible reasons schoolchildren were enrolled on a transversal study performed at each one of the 39 school units, one per community and two per urban area (32 from Berilo and seven from José Gonçalves de Minas).

Informed written consent was obtained from all participants through their parents or legal guardians. This work complied with resolution number 196/1996 from the National Health Council for research involving humans and was approved by the Ethical Committee at Centro de Pesquisas René Rachou (CPqRR), Belo Horizonte, MG, Brazil, Process 07/2002.

Standardization of ELISA in blood eluate from filter paper (ELISA-BEFP): $T$. cruzi Y strain epimastigote antigen was obtained by alkaline extraction according to VITOR \& CHIARI ${ }^{31}$. The protein content was determined by LOWRY et al. ${ }^{19}$. To standardize the ELISA$B E F P$, the alkaline antigen concentration was tested at $1.5 \mu \mathrm{g} / \mathrm{mL}, 3.0$ $\mu \mathrm{g} / \mathrm{mL}, 4.5 \mu \mathrm{g} / \mathrm{mL}$ and $6.0 \mu \mathrm{g} / \mathrm{mL}$. Peroxidase conjugated anti-human IgG was tested at 1:1000, 1:2500, 1:5000 and 1:10,000 in PBS-Tween 20. Reference positive and negative controls were tested at 1:40, 1:80, $1: 100,1: 120,1: 160$ and 1:320 dilutions in PBS-Tween 20. After standardization procedures, experimental design was better established using antigen at $4.5 \mu \mathrm{g} / \mathrm{mL}$; peroxidase conjugated anti-human IgG at 1:1000 and control samples at 1/80 (data not shown). To determine the better elution procedures, blood samples from six filter paper disks with $5 \mathrm{~mm}$ of diameter each was eluted by shaking during 20 minutes using $200 \mu \mathrm{L}, 250 \mu \mathrm{L}, 300 \mu \mathrm{L}, 340 \mu \mathrm{L}, 380 \mu \mathrm{L}$ and $420 \mu \mathrm{L}$ of PBSTween 20 to obtain six distinct sample dilutions. Using the standardized procedures, the six BEFP dilutions were tested to determine which elution index better associate with the optical density (OD) results obtained for the sera sample from the same donor at $1 / 80$. It was observed that BEFP at $250-300 \mu \mathrm{L}$ interval gave the better association in comparison to the OD obtained with the reference sera samples. Considering previous reports of MACHADO-COELHO ${ }^{21}$ the BEFP was prepared using the $280 \mu \mathrm{L}$ of PBS-Tween 20. Comparative analysis was carried out using a range of paired samples.

Screening serology by ELISA using BEFP: A blood sample was first collected on filter-paper Whatman No. 4 from all participants for screening serological diagnosis of $T$. cruzi infection. Afterwards, filter papers were dried at room temperature, kept in an identified plastic envelop containing silica gel, at $4{ }^{\circ} \mathrm{C}$.

The ELISA test was performed according to the methodology of VOLLER et al..$^{32}$ modified using $4.5 \mu \mathrm{g} / \mathrm{mL}$ of antigen concentration, peroxidase-conjugated anti-human $\operatorname{IgG}$ conjugate diluted 1/1000 and BEFP diluted 1:80 in PBS-Tween 20, correspondent to the standardized methodology ${ }^{31}$. The OD was determined using $490 \mathrm{~nm}$ filter (SOFTMAX $^{\circledR}$ PRO 4.0- Life Sciences edition). The cut-off edge was established considering the mean absorbance values of 10 negative sample sera + three standard deviations to segregate samples with positive and negative results. Sensitivity and specificity of ELISABEFP have been described elsewhere considering IFAT as the "gold standard" and include co-negativity $=1$ and co-positivity of 0.99 . The referred sensitivity of IFAT was $86 \%{ }^{21}$.

Confirmatory serological tests: After the screening test, samples were collected from all children with positive results on the ELISABEFP and from those with OD values next to the cut-off edge. Conventional serological tests were performed as recommended by the World Health Organization and Brazilian Health Ministry ${ }^{7,33}$ that recommend the use of at least two serological tests, with distinct principles to confirm the diagnosis of Chagas disease.

Four methodologies of distinct principles were used, including inhouse conventional ELISA test (ELISA), recombinant-ELISA (EIERec-ELISA) using CRA+FRA ${ }^{17,18}$ T. cruzi recombinat antigens, Indirect Immunofluorescence test (IIF), both from BIO-Manguinhos and Indirect Hemaglutination assay (IHA) from Immunoserum. The ELISA test was performed using the standardized methodology described above for BEFP screening tests. The EIE-Rec-ELISA, IIF and IHA were carried out following the fabricant recommendations. The IHA were carried out by Chagas disease Reference Service, Fundação Ezequiel Dias (FUNED), Belo Horizonte, MG, Brazil. 


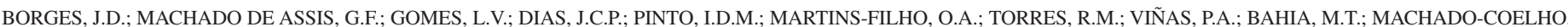

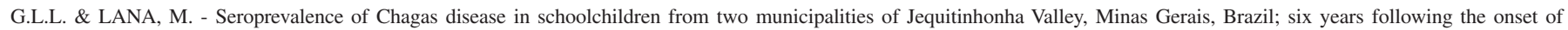
epidemiological surveillance. Rev. Inst. Med. trop. S. Paulo, 48(2):81-86, 2006.

Study of seropositive cases: Seropositive children were evaluated by: (a) clinical-epidemiologial questionnaire; (b) physical examination; (c) conventional electrocardiogram; (d) thoracic x-ray (PA) and (e) hemoculture.

The application of clinical-epidemiological questionnaire was performed by health attendants and the physicians, previously trained by our clinical team. The clinical examination was performed by our clinical team. For hemoculture a volume of 15 to $20 \mathrm{~mL}$ of blood collected with heparin and processed according to CHIARI et al. ${ }^{10}$ methodology modified by LUZ et al. ${ }^{20}$ was used. Search for parasites was performed by light microscopy, each 15 days during 120 days. The parents of seropositive children were also examined by immunoserological tests (ELISA and IHA) and hemoculture.

Etiological treatment: All children with confirmed diagnosis of Chagas disease were treated with classical scheme of benznidazol $\left(\right.$ Roche $^{\circledR}$ ) therapy using a daily dose of $8 \mathrm{mg} / \mathrm{kg}$ of body weight by oral route, during 60 consecutive days, according to $\mathrm{CANÇADO}^{8}$. Treatment was started only after the signature of informed written consent obtained from all participants through their parents or legal guardians.

\section{RESULTS}

Screening serology: The screening immunoassay performed by ELISA using BEFP identified $2.69 \%(38 / 1,412)$ of schoolchildren as positive for anti-T. cruzi $\mathrm{IgG}$, including $1.89 \%$ in Berilo and $3.88 \%$ from José Gonçalves de Minas. Positivity was detected in 26 males $(1.84 \%)$ and 12 females $(0.85 \%)$ (Table 1$)$.

Table 1

Anti-Trypanosoma cruzi IgG reactivity in schoolchildren from Berilo and José Gonçalves de Minas, Jequitinhonha Valley, Minas Gerais, Brazil

\begin{tabular}{|c|c|c|c|}
\hline \multirow[t]{2}{*}{ Test Category } & \multicolumn{3}{|c|}{ ELISA Positive IgG Reactivity (\%) } \\
\hline & $\begin{array}{c}\text { Total } \\
(1412)^{*}\end{array}$ & $\begin{array}{l}\text { Berilo } \\
(846)^{*}\end{array}$ & $\begin{array}{c}\text { JGM } \\
(566)^{*}\end{array}$ \\
\hline \multicolumn{4}{|c|}{ Screening immunoassay } \\
\hline ELISA $\dagger$ & $38(2.69)$ & $16(1.89)$ & $22(3.88)$ \\
\hline Male & $26(1.84)$ & $11(1.30)$ & $15(2.65)$ \\
\hline Female & $12(0.85)$ & $05(0.59)$ & $07(1.23)$ \\
\hline \multicolumn{4}{|c|}{ Confirmatory immunodiagnosis } \\
\hline ELISA & $07(0.49)$ & $04(0.47)$ & $03(0.53)$ \\
\hline EIE-Rec-ELISA & $06(0.42)$ & $03(0.35)$ & $03(0.53)$ \\
\hline IIF & $06(0.42)$ & $03(0.35)$ & $03(0.53)$ \\
\hline IHA & $06(0.42)$ & $03(0.35)$ & $03(0.53)$ \\
\hline
\end{tabular}

* Data expressed as percentage. †ELISA was performed using BEFP; JGM = José Gonçalves de Minas.

Confirmatory anti-T. cruzi IgG antibody serology: According to the confirmatory immunodiagnosis for Chagas disease we have found six out of the 38 cases first identified with positive results by the screening ELISA-BEFP, leading to a total prevalence of $0.42 \%$, including three cases $(0.35 \%)$ from Berilo and three cases $(0.53 \%)$ from José Gonçalves de Minas (Table 1). No significant differences were observed on seropositive male and female between the two municipalities.

Descriptive study of seropositive cases: The confirmed seropositive cases included four males and two females, with age ranging from nine to 14 years. Five out of six cases were 11-14 years old. Additional analysis revealed that three cases proceeded from Berilo, included two males and one female, with age ranging from 9-13 years, living in two rural communities. The other three cases proceeded from José Gonçalves de Minas, included two males and one female with age ranging from 11-14 years. Two of them live in rural communities and one at main town.

The epidemiological investigation of seropositive children revealed relevant antecedents compatible with those observed in chagasic population from endemic areas such as: habitants of rural areas or coming from it. Despite one case, all other infected schoolchildren were from rural communities (Córrego dos Coqueiros and Lagoinha from Berilo Municipality and Vargem do Pombo and Ribeirão Pequeno from José Gonçalves de Minas Municipality). Moreover, other important antecedents including: descendency of chagasic parents, reports of Chagas disease relatives, reports of heart disease and sudden death in family, peridomiciliary and house predisposing environment features for Chagas disease transmission, recognition of local triatomine species reporting its presence in their agriculture fields, report of presence of natural reservoirs at house environment without linking them with the disease epidemiology, habitant of adobe houses typical of low social-economic level (Table 2).

The clinical and physical examination revealed that all children were asymptomatic, except one student, who showed enlargement of P-r interval (Pri) of 0.22 seconds. The hemoculture was positive in all children examined (5/5), and in the majority (3) children it became positive within the first month of blood cultivation in LIT media. The serology was positive in all mothers and in three out of five fathers. The hemoculture was also positive in $5 / 5$ mothers examined. All seropositive children were treated with benznidazol (Rochagan $\AA$, Roche) and are currently under follow-up.

\section{DISCUSSION}

Chagas disease is a typical antropozoonosis dependent on several bioecological elements as well as cultural and social economical factors ${ }^{13}$. The epidemiological surveillance of Chagas disease, in areas where the anti-vectorial program was implemented is extremely important to guarantee the successful control of disease transmission ${ }^{14}$. Still, a well accomplished epidemiological surveillance become even more important in regions where the vector species involved in the transmission are often observed in peridomicile. The new challenges concerning this disease in areas under vector control are basically to implement and maintain a sustainable entomological surveillance and to detect and to provide medical attention for already infected individuals $\mathrm{s}^{13}$.

Despite some Brazilian states have recently received the certificate of interruption of vectorial Chagas disease transmission ${ }^{34}$, the epidemiological surveillance program for Chagas disease in Brazil is currently suffering discontinuity as consequence of politics of public 


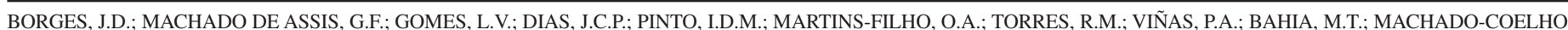
G.L.L. \& LANA, M. - Seroprevalence of Chagas disease in schoolchildren from two municipalities of Jequitinhonha Valley, Minas Gerais, Brazil; six years following the onset of epidemiological surveillance. Rev. Inst. Med. trop. S. Paulo, 48(2):81-86, 2006.

Table 2

Major epidemiological antecedents relevant to Chagas disease observed on six Trypanosoma cruzi seropositive cases from Berilo and José Gonçalves de Minas, Jequitinhonha Valley, Minas Gerais, Brazil

\begin{tabular}{|c|c|c|c|}
\hline Epidemiological antecedents & Total & Berilo & JGM \\
\hline Relatives with Chagas disease (parents, uncles and grandparents) & 6 & $3 / 3$ & $3 / 3$ \\
\hline Heart disease in family (parents, uncles and grandparents) & 5 & $2 / 3$ & $3 / 3$ \\
\hline Sudden death in family (uncles and grandparents) & 2 & $1 / 3$ & $1 / 3$ \\
\hline Recognition of local triatomine species & 2 & $2 / 3$ & 0 \\
\hline Peridomiciliary chicken & 3 & $1 / 3$ & $2 / 3$ \\
\hline Dogs and rats in house & 4 & $3 / 3$ & $1 / 3$ \\
\hline Cats in house & 2 & $1 / 3$ & $1 / 3$ \\
\hline Reports of opossum in house & 2 & $1 / 3$ & $1 / 3$ \\
\hline Adobe house at birth & 4 & $3 / 3$ & $1 / 3$ \\
\hline Adobe house at present & 3 & $3 / 3$ & 0 \\
\hline Access to treated water & 4 & $3 / 3$ & $1 / 3$ \\
\hline
\end{tabular}

JGM = José Gonçalves de Minas.

health. Relevant changes on national health institutions, such as FUNASA, early responsible for the control of major Brazilian endemic diseases, including Chagas disease ${ }^{14}$, pointed out the increasing need for implementation of additional efforts to control disease outbreaks. Moreover, it is important to notice that the Chagas disease control program had been implemented in the Jequitinhonha Valley, Minas Gerais State, from 1970 to 1980 , but suffered interruptions in 1990, 1991, 1995 and 1996, exactly when five out of the six infected children were born ${ }^{22}$.

The main goal of this work was to verify whether the transmission of Chagas disease was interrupted or kept on going in the municipalities of Berilo and José Gonçalves de Minas, located at Jequitinhonha Valley, MG, Brazil. Herein, the screening immunoassay by ELISA using BEFP detected $2.69 \%$ of seropositivity $(38 / 1,412)$. This higher positivity in screeening tests for Chagas disease in BEFP in relation to serology was observed by MACHADO-COELHO ${ }^{21}$ and also by MONTOYA et $a l .{ }^{23}$. Our results of seroprevalence of $0.4 \%$ in schoolchildren were similar to those observed by this author in zero to nine year-old children in the same area, six years before. Although we could not say if the children evaluated were the same, our age group corresponds to the one to eight year-old group of MONTOYA ${ }^{22}$. However, this prevalence is lower that the one described by AGUILAR ${ }^{1}$ who detected $1.6 \%$ of seropositive children younger than 10 year-old and it is interesting to note that all seropositive children identified in our investigation were born before the beginning of the epidemiological surveillance for Chagas disease in this region. These data are suggestive of a positive impact of Chagas disease control program adopted by these two municipalities, if considered that our investigation was carried out six years later than that performed by MONTOYA et al. ${ }^{23}$.

However, in the interpretation of these results is important to consider some bias inherent to epidemiological descriptive design that could decrease the power of the inference about the prevalence in this studied area. Although the selection bias was controlled using a random sample stratified by proportion of children in each school unit, random variation may occurs among different studies, and because all children were enrolled at school. The information bias was minimized since our samples were stored at $4{ }^{\circ} \mathrm{C}$ in silica gel and all positive cases were confirmed in block by sera samples in a blinding way. Similarly, although the techniques were standardized, differences in sensibilities of reagents used by different authors could change the results of different surveys. Another bias that should be taken into account is the children mortality during this six-year period.

Recent investigations concerning seroprevalence in children in Latin America have demonstrated the importance of seroprevalence of Chagas disease in children as a reliable indicator of transmissibility of the disease $^{4,16}$

The presence of $P$. megistus in these two municipalities, a peridomiciliar vector species, shows the need of strengthening the Chagas disease control program. The high seroprevalence of Chagas disease in women in procreative age reported by MONTOYA ${ }^{22}$ in these municipalities also implies the possibility of vertical transmission of Chagas disease, reforcing the need of further investigation on this issue to prevent congenital T. cruzi infection. It is plausible to hypothesize that these children became infected by vectorial transmission since $P$. megistus still remains the major vector species detected in this region ${ }^{22}$ ${ }^{25}$. However, another hypothesis to be considered is the possibility of vertical transmission, since all mothers showed to be seropositive for Chagas disease and $5 / 5$ of them presented positive hemoculture.

Although CARNEIRO et al. ${ }^{9}$ demonstrated that children seropositive for Chagas disease from other municipalities under epidemiological surveillance showed higher probability of having mother and relatives also seropositive, additional studies are necessary to elucidate the real mechanisms involved in the transmission, since congenital infection seems to be rare in Berilo and José Gonçalves de Minas $^{22}$ as well as in Minas Gerais State ${ }^{15}$ and Brazil ${ }^{25}$.

The infected schoolchildren were predominantly male (four males and two females). In general, considering the universe of schoolchildren evaluated (07-14), the general seropositivity was predominant in older children (09-14), with 5/6 of them with 11 to 14 years. However, when considering the two municipalities in separate analysis, Berilo showed seropositivity predominance in younger children (09-13) while José Gonçalves de Minas showed evidence of older children (11-14). 


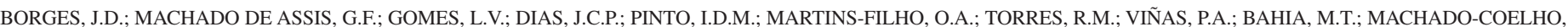

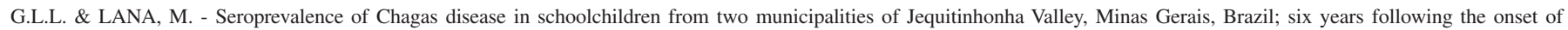
epidemiological surveillance. Rev. Inst. Med. trop. S. Paulo, 48(2):81-86, 2006.

Although a study of risk factors (case/control) had not been performed, herein the epidemiological data concerned to the infected children and their relatives revealed several aspects usually observed in chagasic population of endemic area, including reports of Chagas disease in their families, presence of reservoirs of the infection, type of house and social economic conditions.

The evaluation of those children with positive serodiagnosis of Chagas disease by local physician and our group, based on anamnesis and physical examination, thoracic X-ray and ECG, led to classify five out of the six children as typical asymptomatic carriers. However, one of the infected children showed an enlarged Pri, which could be an early and transient ECG Chagasic alteration, frequently found in chagasic children during and after the acute phase of the infection ${ }^{13,23,26}$. Similar findings were previously reported regarding the high prevalence of early ECG abnormalities in T. cruzi infected children ${ }^{3}$. Additional clinical and laboratorial examination focusing on cardiac function evaluation would be necessary to determine the precise clinical form of this infected child.

All infected children were submitted to the etiological treatment with benznidazole, according to the Second Report of the WHO Expert Committee $^{35}$. Further periodical clinical and laboratorial evaluations after treatment will be performed aiming to verify the parasitological cure and the impact of chemotherapy on the evolution of the disease. Considering the age of the individuals and the genetic of the parasite detected in the area, mainly T. cruzi II isolates ${ }^{11}$, the expectative of the authors is optimist since the benefit effects of chemotherapy can be better in young people or recent infections in both cure ${ }^{2,6,29}$ and prognosis of the infection $5,26,28,30$.

In conclusion, our findings suggest the urgent need of efforts to guarantee the continuous success of Chagas disease control in Berilo and José Gonçalves de Minas Municipalities. In this context, the accuracy and well-defined improvement of local Health Public System (SUS) as well as the generation of qualified human resources and competences are of major relevance as previously suggested by DIAS ${ }^{14}$. Meanwhile, we are working with the health team in Berilo. Moreover, we are currently re-evaluating the profile of vector distribution in both municipalities in collaboration with the team of the Minas Gerais State Health Secretary (SES-MG). We believe that this investigation will indicate important information to further improvement of the epidemiological surveillance of the disease in this region.

\section{RESUMO}

Soroprevalência da doença de Chagas em escolares de dois municípios do Vale do Jequitinhonha, Minas Gerais, Brasil, seis anos após a implantação da vigilância epidemiológica

Seis anos após o início da vigilância epidemiológica para doença de Chagas em Berilo e José Gonçalves de Minas, Vale do Jequitinhonha, MG, Brasil, foi realizado um inquérito sorológico para verificar se a transmissão desta endemia estava ocorrendo naquela área. Uma amostra aleatória de 1.412 crianças, de 7 a 14 anos, foi avaliada. Foram encontradas seis crianças positivas assintomáticas, totalizando uma prevalência de $0,4 \%$. Hemocultura confirmou a infecção em cinco dos seis casos positivos. Uma investigação epidemiológica adicional, revelou importantes antecedentes, tais como: casos da doença em parentes e condições de moradia e ecológicas predisponentes. Nossos resultados demonstram uma soroprevalência similar $(0,4 \%)$ em escolares de 7 a 14 anos àquela observada há seis anos $(0,2 \%)$ em crianças de 0-9 anos. Dessa forma, considerando a presença constante de Panstrogylus megistus estes achados reforçam a necessidade de uma vigilância epidemiológica contínua e aperfeiçoada para Doença de Chagas naquela região.

\section{ACKNOWLEDGEMENTS}

We are thankful to the Berilo and José Gonçalves de Minas municipal authorities and health local team for their unconditional support for the development of this study. We would like to thank, Dr Bernardino Vaz de Melo Azeredo from Superintendência de Epidemiologia, Programa de Controle da Doença de Chagas, Secretaria Estadual de Saúde de Minas Gerais Brazil, for his support during the development of this study. We are grateful to FAPEMIG, CNPq, SESU/ MEC and PROEX/UFOP for the financial support.

\section{REFERENCES}

1. AGUILAR, H.M. - Epidemiologia da doença de Chagas: aspectos históricos, sociais e morbidade em duas áreas endêmicas de Minas Gerais, Brasil. Rio de Janeiro, 1988. (Dissertação de Mestrado - Instituto Oswaldo Cruz).

2. ANDRADE, A.L.; ZICKER, F.; OLIVEIRA, R.M.; ALMEIDA SILVA, A.S. et al Randomised trial of efficacy of benznidazole in treatment of early Trypanosoma cruzi infection. Lancet, 348: 1407-1413, 1996.

3. ANDRADE, A.L.; ZICKER, F.; RASSIS, A. et al. - Early electrocardiographic abnormalities in Trypanosoma cruzi-seropositive children. Amer. J. trop. Med. Hyg., 59: 530-534, 1998.

4. ANEZ, N.; CRISANTE, G. \& ROJAS, A. - Update on Chagas disease in Venezuela: a review. Mem. Inst. Oswaldo Cruz, 99: 781-787, 2004.

5. BAHIA-OLIVEIRA, L.M.G.; GOMES, J.A.S; CANÇADO, J.R. et al. - Immunological and clinical evaluation of chagasic patients subjected to chemotherapy during the acute phase of Trypanosoma cruzi infection 14-30 years ago. J. infect. Dis., 182: 634-638, 2000.

6. BRASIL. Ministério da Saúde. Superintendência de Campanha de Saúde de Minas Gerais - Campanha de controle da doença de Chagas: ficha epidemiológica de localidade do Município de Berilo. Diamantina, FUNASA; Divisão de doença de Chagas, 1982.

7. BRASIL. Ministério da Saúde - Normas técnicas para coleta, processamento e transfusão de sangue, componentes e derivados. Diário Oficial da União, (Portaria nº. 721), 1998.

8. CANÇADO, J.R. - Terapêutica específica. In: DIAS, J.C.P. \& COURA, J.R., ed. Clínica e terapêutica da doença de Chagas. Uma abordagem prática para o clínico geral. Rio de Janeiro, FIOCRUZ, 1997. p. 323-351.

9. CARNEIRO, M.; MORENO, E.C. \& ANTUNES, C.M.F. - Nested case-control study in a serological survey to evaluate the effectiveness of a Chagas disease control programme in Brazil. Bull. Wld Hlth Org., 79: 409-414, 2001.

10. CHIARI, E.; DIAS, J.C.P.; LANA, M. \& CHIARI, C.A. - Hemoculture for the parasitological diagnosis of human chronic Chagas' disease. Rev. Soc. bras. Med. trop. 22: 19-23, 1989.

11. DEVERA, R.; ILLARRAMENDI, X.; MONTOYA-ARAÚJO, R. et al. - Biodemas de cepas do Trypanosoma cruzi isoladas de humanos de três áreas endêmicas de Minas Gerais. Rev. Soc. bras. Med. trop., 35: 323-330, 2002. 


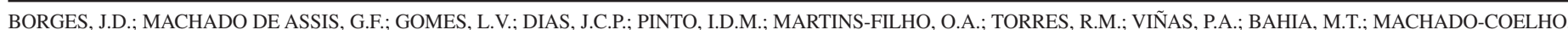
G.L.L. \& LANA, M. - Seroprevalence of Chagas disease in schoolchildren from two municipalities of Jequitinhonha Valley, Minas Gerais, Brazil; six years following the onset of epidemiological surveillance. Rev. Inst. Med. trop. S. Paulo, 48(2):81-86, 2006.

12. DIAS, J.C.P.; LOYOLA, C.C.P. \& BRENER, S. - Doença de Chagas em Minas Gerais: situação atual e perspectivas. Rev. bras. Malar., 37: 7-28, 1985.

13. DIAS, J.C.P. \& COURA, J.R. - Epidemiologia. In: DIAS, J.C.P. \& COURA, J.R., ed. Clínica e terapêutica da doença de Chagas. Uma abordagem prática para o clínico geral. Rio de Janeiro, FIOCRUZ, 1997. p. 33-65.

14. DIAS, J.C.P. - Vigilância epidemiológica em doença de Chagas. Cadern. Saúde públ., 16 (supl. 2): 43-59, 2000.

15. DIAS, J.C.P. - O controle da doença de Chagas no Brasil. In: SILVEIRA, A.C., ed. O controle da doença de Chagas nos países do Cone Sul da América. História de uma iniciativa internacional (1991-2001). Uberaba, Faculdade de Medicina do Triângulo Mineiro; OPAS, 2002. p. 145-268.

16. DIOSQUE, P.; PADILLA, A.M.; CIMINO, R.O. et al. - Chagas disease in rural areas of Chaco Province, Argentina: epidemiologic survey in humans, reservoirs, and vectors. Amer. J. trop. Med. Hyg., 71: 590-593, 2004.

17. GOMES, Y.M.; PEREIRA, V.R.A.; NAKAZAWA, M. et al - Serodiagnosis of chronic Chagas infection by using EIE-Recombinant-Chagas-Biomanguinhos kit. Mem. Inst. Oswaldo Cruz, 96: 497-501, 2001.

18. LAFAILLE, J.J.; LINSS, J.; KRIEGER, M.A. et al - Structure and expression of two Trypanosoma cruzi genes encoding antigenic proteins bearing repetitive epitopes. Molec. Biochem. Parasit., 35: 127-136, 1989.

19. LOWRY, O.H.; ROSEBROUGH, N.J.; FARR, A.L. \& RANDALL, R.J. - Protein measurement with the folin phenol reagent. J. biol. Chem., 193: 265-275, 1951.

20. LUZ, Z.M.P.; COUTINHO, M.G.; CANÇADO, J.R. \& KRETTLI, A.U. - Hemocultura: técnica sensível na detecção do Trypanosoma cruzi em pacientes chagásicos na fase crônica da doença de Chagas. Rev. Soc. bras. Med. trop., 27: 143-148, 1994.

21. MACHADO-COELHO, G.L.L. - Avaliação da utilização do eluato de sangue dessecado em papel de filtro no diagnóstico sorológico da infecção pelo Trypanosoma cruzi. Belo Horizonte, 1990. (Dissertação de Mestrado - Universidade Federal de Minas Gerais).

22. MONTOYA, R.A. - Morbidade da doença de Chagas no município de Berilo, Minas Gerais, Brasil. Estudos seccional e longitudinal da cardiopatia chagásica crônica (1987-1997). Rio de Janeiro, 1998. (Tese de Doutorado - Instituto Oswaldo Cruz).

23. MONTOYA, R.; DIAS, J.C.P. \& COURA, J.R. - Chagas disease in a community in southeast Brazil. I. A serologic follow-up study on a vector controlled area. Rev. Inst. Med. trop. S. Paulo, 45: 269-274, 2003.
24. MORENO, E.C. \& BARACHO, L. - Vigilância epidemiológica no programa de controle da doença de Chagas em Minas Gerais, Brasil (1984-1998). Cadern. Saúde públ., 16(supl. 2): 113-116, 2000

25. PRATA, A. - Evolution of the clinical and epidemiological knowledge about Chagas disease 90 years after its discovery. Mem. Inst. Oswaldo Cruz 94(supl. 1): 8-88, 1999.

26. SEGURA, M.A.; MOLINA, E.R. \& BASOMBRIO, M.A. - Reversibility of muscle and heart lesions in chronic Trypanosoma cruzi infected mice after late trypanomicidal treatment. Mem. Inst. Oswaldo Cruz, 89: 213-216, 1994.

27. SILVEIRA, A.C. \& RESENDE, D.F. - Epidemiologia e controle da transmissão vetoria da doença de Chagas no Brasil. Rev. Soc. bras. Med. trop., 27(supl. 3): 11-22, 1994.

28. SOSA-ESTANI, S.; SEGURA, E.E.; RUIZ, A.M. et al. - Efficacy of chemotherapy with benznidazole in children in the indeterminate phase of Chagas' disease. Amer. J. trop. Med. Hyg., 59: 526-529, 1998.

29. STREIGER, M.L.; DEL BARCO, M.L.; FABBRO, D.L.; ARIAS, E.D. \& AMICONE, N.A. - Estudo longitudinal e quimioterapia específica em crianças, com doença de Chagas crônica, residentes em área de baixa endemicidade da República Argentina. Rev. Soc. bras. Med. trop., 37: 365-375, 2004.

30. VIOTTI, R.; VIGLIANO, C.; ARMENTI, A. \& SEGURA, E.L. - Treatment of chronic Chagas' disease with benznidazole: clinical and serologic evolution of patients with long-term follow-up. Amer. Heart J., 127: 151-162, 1994.

31. VITOR, R.W.A. \& CHIARI, E. - Avaliação de antígenos do Trypanosoma cruzi para a reação de hemaglutinação indireta. I. Diferentes estratos antigênicos. Rev. Inst. Med. trop. S. Paulo, 29: 178-182, 1987.

32. VOLLER, A.; BIDWELL, D. \& BARTLETT, A. - Enzyme immunoassays in diagnostic medicine. Theory and practice. Bull. Wld Hlth Org., 53: 55-65, 1976.

33. WORLD HEALTH ORGANIZATION - Control of Chagas Disease. Wld Hith Org techn. Rep. Ser., (811): 38-47, 1991.

34. WORLD HEALTH ORGANIZATION - Chagas disease, Brazil - interruption of transmission. Wkly epidem. Rec., 75(19): 153-160, 2000.

35. WORLD HEALTH ORGANIZATION. - Control of Chagas disease: second report of the WHO Expert Committee. Wld HIth Org. techn. Rep. Ser., (905): 1-109, 2002.

Received: 18 July 2005

Accepted: 15 December 2005 